\title{
MEASUREMENT OF THE AVERAGE INNOVATIVENESS CHANGE OVER TIME IN THE EU MEMBER STATES
}

\author{
Elżbieta ROSZKO-WÓJTOWICZ1 ${ }^{*}$, Jacek BIAŁEK ${ }^{2}$ \\ ${ }^{1}$ Department of Economic and Social Statistics, University of Lodz, Lodz, Poland \\ ${ }^{2}$ Department of Statistical Methods, University of Lodz, Lodz, Poland
}

Received 05 September 2018; accepted 24 January 2019

\begin{abstract}
In the age of globalisation, implementation and commercialisation of new technologies are perceived as key elements determining competitiveness of particular countries, therefore, the growth of innovativeness is seen as the predominant direction of European Union society's transformation into information society. The aim of the paper is to propose a procedure of measurement of innovativeness growth over time, with the Summary Innovation Index (SII) methodology as a starting point. The considered issue can be expressed by the following main question: how to measure the innovation performance dynamics for a selected group of countries (such as the EU28, EU-15 or EU-13 countries) and for time intervals (not only for two moments of observations). This is an important inquiry since well-known innovativeness indices (SII, GII, or IOI) concentrate mainly on the provision of information about countries' innovation performance for a specific year of observations. Due to this fact, changes occurring over longer time periods are rather neglected. The main result of the paper is a proposition of average innovativeness growth index. The index uses weights describing the employment share of a selected group of specialists (e.g.: scientists and engineers, research and development personnel) in relation to the economically active population.
\end{abstract}

Keywords: innovativeness measurement, Summary Innovation Index, innovativeness growth, index theory, European Union.

JEL Classification: C43, C30, O30.

\section{Introduction}

In the contemporary world, innovative activity is a vital factor of competitiveness and longterm economic growth of a country. New products, utility models, trademarks, and creative projects are important elements of present socio-economic reality. Innovation is also an important objective of policy intervention. In the age of globalisation, implementation and commercialisation of new technologies are perceived as key elements determining competitiveness of particular countries. Therefore, smart specialisation and knowledge-intensive

*Corresponding author. E-mail: elzbieta.roszko@uni.lodz.pl 
development (i.e. development based on knowledge-intensive activities) are perceived as the predominant direction of changes that should be occurring in the European Union's (EU) societies, enabling continuous growth of innovativeness. European countries' innovativeness has been assessed by the European Commission on a regular basis and this consolidated assessment is published in the European Innovation Scoreboards (EIS). The aim of the paper is to develop and discuss a procedure for measuring changes in innovativeness levels in the EU on the basis of the Summary Innovation Index (SII) methodology. The following research question has been formulated based on the set objective: how and by what means is the dynamics of changes in innovativeness measured in the case of a selected group of states (e.g.: the EU-28, EU-15 or EU-13) over a specific period of time (not only for two observation moments)? On this basis, an attempt to verify the main hypothesis that the dynamics of the level of innovativeness of the entire EU (both on an annual basis and within any comparable time interval) differs from the analogical assessment of a selected subgroup (e.g.: the EU 13, EU 15, V4) has been made in the paper. For a broader illustration of the issue of changes in the level of innovativeness over time, a specific hypothesis has been also formulated stating that changes in the level of innovativeness (from year to year) in the last few years are not expressed as a function growing over time. In the considered period of time, the dynamics of innovation performance either slowed down or was characterised by a lack of a clear trend and significant fluctuations.

The measurement of changes in the innovativeness level over time is rather neglected in the literature, as indicated by our previous research. Well-known international reports concentrate mainly on presenting innovation performance from the perspective of one moment in time. Even if changes occurring over time are discussed, they are usually, if not only, presented by the application of simple methods, changes in absolute values or simple indices. We find it interesting to look at this subject from a different perspective, focusing on the measurement of changes in the innovativeness level over time.

The issue under discussion is important since the innovation indices presented in the literature the Summary Innovation Index - SII, the Global Innovation Index - GII, the Innovation Output Indicator - IOI focus on providing information on the level of a country's innovativeness for a given year of observation. As a result, there is no information on the dynamics of changes in innovativeness over a specific time period. The aim of the paper is to analyse the dynamics of SII and chosen sub-indices under the influence of selected additional weights describing the employment share of a selected group of specialists (e.g.: scientists and engineers) in relation to the economically active population. The main result of the paper is a proposition of average innovativeness growth index. On the basis of this index, the dynamics of the EU countries' innovation performance is measured and assessed. The time period considered covers data from 2010 till 2016. The research data include values of the Summary Innovation Index and six system of weights.

The paper consists of an introduction, four separate substantive sections and a summary. The section devoted to a literature review consists of the presentation of two theoretical threads. The first one shows the relationship between competences of workforce and the possibilities of generating innovation in the economy. This part of the literature review will primarily provide the justification for the weights included in the construction of the index 
selected in the course of the statistical procedure. The other element of the literature review is directly related to the applicability of index theory to the construction of an index measuring the average level of innovativeness (average change over time in the level of innovativeness). The subsequent part of the paper is devoted to the presentation and discussion of statistical data. Next, the implementation of the research process with its assumptions is described in detail. The results of the analysis conducted are presented in Section 5.

\section{Theoretical background}

\subsection{Knowledge economy, skills and innovation}

A starting point for further considerations presented in this paper is the assumption about the existence of a close relationship between knowledge and innovation. The dissemination of knowledge generates further innovations (Mačiulytė-Šniukienė \& Matuzevičiūtė, 2018; Roszko-Wójtowicz \& Białek, 2017; Johansson, 2014; Niklewicz-Pijaczyńska \& Wachowska, 2012). The justification for this state of affairs can be found in the following two factors: the process of globalisation of economies (Lu, Tsang, \& Peng, 2008; Veugelers, 2010) and fast technological changes (Santos, Doz, \& Williamson, 2004; Peng, 2006; Madsen, 2008; Bogliacino \& Vivarelli, 2012; Bogliacino, Piva, \& Vivarelli, 2012; Feldmann, 2013). The nature of research and development activity is also changing, innovations are transforming, their specificity is changing, and their generation is becoming increasingly expensive (Karlsson, Johansson, \& Norman, 2011). This can be seen, for example, in a significant shortening of the time needed to commercialise a technology or an idea. A rapid flow of information and goods means that an innovative product or service has to reach the final recipient in the shortest possible time. Nowadays, the following phenomena are observed: (1) the process of significant acceleration in the creation of new solutions, (2) a growing degree of their complexity (3) globalisation of innovative processes, and (4) an increasing need for cooperation and collaboration of specialists from various disciplines. Currently, innovations are most often created through the integration of knowledge derived from many disciplines and through the cooperation of various specialists (Karlsson et al., 2011; Acs, Audretsch, Braunerhjelm, \& Carlsson, 2009). This results in further consequences regarding qualifications required of employees. One of the most desirable skills is the ability to communicate and the accompanying interdisciplinarity (Williams, Slack, \& Stewart, 2000; Firszt, 2012; Horth \& Vehar, 2014).

Knowledge arises as a result of processing of data and information. Particularly noteworthy is the perception of knowledge as a modern resource of an enterprise (Shanhong, 2002; Vila, Cabrer, \& Pavía, 2015; Huarng \& Mas-Tur, 2016) characterised by specific features such as its dominance among other resources, inexhaustibility or simultaneity (A. Toffler \& H. Toffler, 1980). P. F. Drucker (1992) emphasised knowledge as a key factor for the growth of the entire economy. In his opinion, not land or capital, but knowledge will be the main factor of production in the 21st century. With the development of economies based on innovation and technological progress, a stronger relationship between qualifications of workforce and other production factors becomes evident. Human capital is a factor that determines the differences between organisations and is the basis of competitive advantage not only of en- 
terprises (Chatzkel, 2004) but of entire economies. There is a growing demand for specialists ready to implement innovative processes and introduce new products (Machin, 2003; Piva \& Vivarelli, 2009).

In the knowledge-based economy, the attention is focused on creating solutions conducive to the activities of entities participating in the process of creating knowledge and transforming it into socially and economically useful innovations. In the era of globalisation, the aspirations of many countries are to raise the international competitiveness of their economies. Measures to achieve this objective include government-driven actions, national strategies, as well as regulations affecting the supply of knowledge and new technologies along with regulations increasing demand for knowledge on the part of enterprises. It is also important to create institutional conditions that facilitate and streamline the transition of new ideas/solutions from the conceptual phase to the commercial phase (Steinmueller, 2010). In addition to systemic solutions, one should not underestimate the role of local informal institutions in the process of further exchange of knowledge (Wiig \& Wood, 1995; Geng \& Huang, 2016). At the same time, the motivation of enterprises to search for, exploit and implement scientific, technological and entrepreneurial knowledge is growing. Organisations are focused on creating a new and better market position. From this perspective, innovation is considered as a key to achieve and maintain a competitive advantage of an organisation. "Enhancing the innovative ability in organisations is one of the most important levers to increase profitability and growth in the market" (Dobni, 2010, p. 49).

Although the driving force of the knowledge-based economy is building network relations between the main participants involved in the process of its creation, the most important link in these activities is human capital. A competent and properly educated person, characterised by a pro-active attitude to solving problems and a creative approach to tasks performed, plays a key role in building the knowledge-based economy, and thus in the course of the innovation process (ter Haar, 2018; Firszt, 2012). Only the appropriate resources of knowledge, especially specialist knowledge, embedded in society make the conversion of knowledge into new or significantly improved solutions possible (Węgrzyn, 2015) (converting knowledge into innovation). Research and development, academic research, a skilled labour force as well as other types of knowledge handlers influence production of knowledge and impact the efficiency of knowledge flows (Andersson \& Ejermo, 2004). The number of knowledge handlers, i.e. people who create new knowledge and/or participate in the process of knowledge transfer and dissemination, is growing significantly. Since 1950, there has been a considerable increase in the number of people employed in the R\&D sector and knowledge handlers (Andersson \& Beckmann, 2009). The involvement of knowledge handlers in organisations, especially in academic institutions and corporations, significantly increases patent activity (Andersson \& Ejermo, 2004).

\subsection{Index theory}

As it has been mentioned, the main aim of the paper is to propose a procedure of measurement of innovativeness growth over time, taking the Summary Innovation Index (SII) methodology as a starting point. The considered problem can be expressed by the following main question: how to measure the innovation performance dynamics for a specified group 
of countries (such as the EU-28, EU-15 or EU-13 countries) and for time interval $[s, t]$, i.e. taking into consideration not only two moments of observations $s$ and $t$ but also considering all indirect moments $s+1, s+2, \ldots, t-1$. In statistics, tools for the dynamics measurement in such cases are aggregative indices (Fisher, 1922; von der Lippe, 2007, Balk, 2016a). According to the axiomatic price index theory, indices should satisfy a list of postulates (the so-called: tests - see Balk (1995) or Olt (1996)). In our approach, we do not create any price or quantity index but propose an original index which compares changes of another index (i.e. the Summary Innovation Index). Although the proposed index is far removed from the classical, above-mentioned index theory, it is based on a given list of postulates, too. Moreover, similarly to chain indices (von der Lippe, 2001), it takes into consideration all observation moments from $s$ to $t$, and as in the so-called stochastic approach (Selvanathan, 1989, Clements \& Selvanathan, 2007; Rao \& Hajargasht, 2015), the proposed index is treated as a random variable. Our procedure consists of two steps. Firstly, we construct an index comparing only moments $s$ and $t$. Secondly, we generalise it into the case of the whole time interval. To obtain a system of weights based on harmonic means, we use a quite standard statistical procedure, i.e. we minimise the dispersion of the index formula. Thus, treating partial indices as some random variables, we make our approach similar to the stochastic approach in the index theory (Selvanathan \& Rao, 1994). The final, global index of the average innovativeness change is a double-weighted mean of partial indices. The paper discusses the possibilities of practical application of one of many procedures presented in the literature (Balk, 2016b) related to the construction of indices allowing us to determine the pace of changes in economic phenomena in time periods selected for comparison. In the analysed case, the index presented in the methodological part of the paper should be considered as a certain proposal to measure the dynamics of changes in the level of innovativeness in specific groups of countries (aggregates).

\section{Research data}

The research procedure was carried out on the basis of partial and aggregated statistical data used in the construction of Summary Innovation Index. The European Innovation Scoreboard is the source of information on innovative activity carried out in the individual Member States. To construct the EIS, data from different sources are used, including primary research results as well as administrative data obtained from the European Patent Office and the Office for Harmonisation in the Internal Market. On the basis of individual indicators collected for the EIS, the cyclically prepared Innovation Union Scoreboard, which shows the ranking of the EU countries based on the value of the Summary Innovation Index (SII), is developed. Sub-indices, made up of a specific number of variables, are created for this index. Over the years, the methodology of calculating the SII has evolved, now 27 indicators are collected and used for the construction of Summary Innovation Index. The input layer is mainly described by factors stimulating innovativeness and an enterprise's activities which show innovations implemented at the company level. The output layer is described by effects which reflect the results of innovative activities carried out in the sphere of business activity (European Commission, 2018; Roszko-Wójtowicz \& Białek, 2018; Majerova, 2015). 
Table 1. The structure of Summary Innovation Index based on European Innovation Scoreboard 2018 (source: own elaboration based on European Commission, 2018. European Innovation Scoreboard 2018)

\begin{tabular}{|c|c|c|c|}
\hline \multirow{11}{*}{ 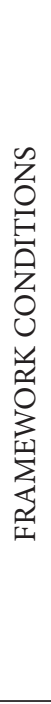 } & Human resources & \multirow{12}{*}{ 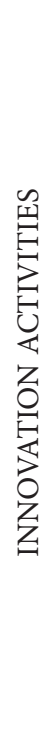 } & Innovators \\
\hline & 1.1.1. New doctorate graduates & & $\begin{array}{l}\text { 3.1.1. SMEs with product or process } \\
\text { innovations }\end{array}$ \\
\hline & $\begin{array}{l}\text { 1.1.2. Population with completed } \\
\text { tertiary education }\end{array}$ & & $\begin{array}{l}\text { 3.1.2. SMEs with marketing or } \\
\text { organisational innovations }\end{array}$ \\
\hline & 1.1.3. Lifelong learning & & 3.1.3. SMEs innovating in-house \\
\hline & Attractive research systems & & Linkages \\
\hline & $\begin{array}{l}\text { 1.2.1. International scientific co- } \\
\text { publications }\end{array}$ & & $\begin{array}{l}\text { 3.2.1. Innovative SMEs collaborating with } \\
\text { others }\end{array}$ \\
\hline & 1.2.2. Top $10 \%$ most cited publications & & 3.2.2. Public-private co-publications \\
\hline & 1.2.3. Foreign doctorate students & & $\begin{array}{l}\text { 3.2.3. Private co-funding of public R\&D } \\
\text { expenditures }\end{array}$ \\
\hline & Innovation-friendly environment & & Intellectual assets \\
\hline & 1.3.1. Broadband penetration & & 3.3.1. PCT patent applications \\
\hline & $\begin{array}{l}\text { 1.3.2. Opportunity-driven } \\
\text { entrepreneurship }\end{array}$ & & 3.3.2. Trademark applications \\
\hline \multirow{8}{*}{ 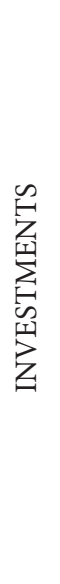 } & Finance and support & & 3.3.3. Design applications \\
\hline & $\begin{array}{l}\text { 2.1.1. R\&D expenditure in the public } \\
\text { sector }\end{array}$ & \multirow{7}{*}{ 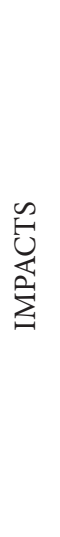 } & Employment impacts \\
\hline & 2.1.2. Venture capital investments & & $\begin{array}{l}\text { 4.1.1. Employment in knowledge-intensive } \\
\text { activities }\end{array}$ \\
\hline & Firm investments & & $\begin{array}{l}\text { 4.1.2. Employment in fast-growing firms in } \\
\text { innovative sectors }\end{array}$ \\
\hline & $\begin{array}{l}\text { 2.2.1. R\&D expenditure in the business } \\
\text { sector }\end{array}$ & & Sales impacts \\
\hline & 2.2.2. Non-R\&D innovation expenditure & & $\begin{array}{l}\text { 4.2.1. Medium and high-tech product } \\
\text { exports }\end{array}$ \\
\hline & \multirow{2}{*}{$\begin{array}{l}\text { 2.2.3. Enterprises providing training to } \\
\text { develop or upgrade ICT skills of their } \\
\text { personnel }\end{array}$} & & 4.2.2. Knowledge-intensive services exports \\
\hline & & & $\begin{array}{l}\text { 4.2.3. Sales of new-to-market and new-to- } \\
\text { firm innovations }\end{array}$ \\
\hline
\end{tabular}

In the latest ranking drawn up for the 28 EU Member States, this breakdown is as follows (European Commission, 2018, p. 13):

The first group comprises Innovation Leaders - these are the countries for which the values of the Summary Innovation Index (SII) are at least $20 \%$ higher than the average for the EU-28. The representatives include: Denmark, Finland, Luxembourg, the Netherlands, Sweden, and the United Kingdom.

The second group comprises Strong Innovators - these are the countries whose average values exceed the average for the EU-28 by less than $20 \%$ and at the same time may be lower than the average by not more than $10 \%$. The representatives include: Austria, Belgium, France, Germany, Ireland, and Slovenia.

The third group comprises Moderate Innovators - these are the countries whose SII values are lower than the average of the EU-28 by more than $10 \%$, but at the same time 
constitute not less than $50 \%$ of the EU-28 average. The representatives include: Croatia, Cyprus, the Czech Republic, Estonia, Greece, Hungary, Italy, Latvia, Lithuania, Malta, Poland, Portugal, Slovakia, and Spain.

The fourth group comprises "catching up" countries, the so-called Modest Innovators these are the countries whose SII values are below 50\% of the average for the EU-28. The representatives include: Bulgaria, and Romania.

Due to the very extensive structure of the Summary Innovation Index (see Table 1), the authors have limited themselves to presenting and discussing in the paper the results of the statistical research with reference to the overall value of the Summary Innovation Index taking into account different groups of countries. The analysis included the EU-28, EU-15, EU-13 and the Visegrad group (V4).

A characteristic element of the groups of countries determined in the research procedure was their wide diversity from the point of view of selected indicators. On the basis of the theoretical discussion presented in Section 2 of this paper indicating that there was a close relationship between innovative activity and the economy's demand for appropriately skilled workforce, it was assumed that the following 6 structure indicators would play the role of weights in assessing the average change over time in the level of innovativeness: (1) persons employed in science and technology in the group age 25-64 years, $\%$ of active population, (2) scientists and engineers, in the group age 25-64 years, \% of active population, (3) research and development personnel in all sectors, \% of the labour force, (4) research and development personnel in the business sector, \% of the labour force, (5) research and development personnel in the government sector, \% of the labour force, and (6) research and development personnel in the higher education sector, $\%$ of the labour force. In this paper, the analysis conducted with the use of the proposed index was carried out for data from the period 2010-2016. The choice of the period of analysis is not accidental. The simultaneous use of data from the European Innovation Scoreboard and data derived from the Eurostat for particular weights made it impossible to extend the time series until 2017. Nevertheless, as far as current data are concerned, the results of the Summary Innovation Index discussed above are based on the latest available data, therefore they include 2017.

The implementation of the research procedure was preceded by verifying the existence of dependencies between the values of the Summary Innovation Index and the individual indicators serving as weights in the proposed index measuring the average level of innovativeness in the European Union. The values of Pearson's linear correlation coefficients are presented in Table 2.

On the basis of partial values of correlation coefficients (Table 2), it should be assumed that only the research and development personnel in the government sector, \% of the labour force variable is not significantly correlated with the Summary Innovation Index or with any of the sub-indices used in its construction. However, a careful assessment of the distribution of this variable leads to the conclusion that low participation of research and development personnel in the government sector may have an impact on the position of a given country in the Summary Innovation Index ranking. It is particularly worth noting the countries that are at the top of this ranking. Of the 10 most developed countries in terms of the level of innovativeness, only in Germany and Luxembourg the government sector is characterised 
Table 2. Evaluation of dependencies between SII sub-indices and individual variables serving as weights (source: own elaboration based on the data of the European Statistical Office - Eurostat and European Commission, 2018. European Innovation Scoreboard 2018)

\begin{tabular}{|c|c|c|c|c|c|c|}
\hline Variable & $\begin{array}{l}\text { Science and } \\
\text { Technology }\end{array}$ & $\begin{array}{l}\text { Scientists and } \\
\text { Engineers }\end{array}$ & All & Business & $\begin{array}{l}\text { Govern- } \\
\text { ment }\end{array}$ & $\begin{array}{l}\text { Higher } \\
\text { Education }\end{array}$ \\
\hline $\begin{array}{l}\text { Summary } \\
\text { Innovation Index }\end{array}$ & $0.865132^{\star}$ & $0.805138^{\star}$ & $0.919985^{\star}$ & $0.898909^{*}$ & -0.081343 & $0.670077^{\star}$ \\
\hline Human resources & $0.471060^{*}$ & $0.444695^{\star}$ & $0.402044^{*}$ & $0.409899^{*}$ & -0.110623 & 0.314346 \\
\hline Research systems & $0.715518^{\star}$ & $0.528131^{*}$ & $0.660569^{*}$ & $0.559509^{*}$ & 0.045924 & $0.627466^{*}$ \\
\hline $\begin{array}{l}\text { Finance and } \\
\text { support }\end{array}$ & $0.584879^{\star}$ & $0.560025^{\star}$ & $0.744719^{*}$ & $0.759451^{*}$ & -0.037016 & $0.463426^{*}$ \\
\hline Firm investments & $0.768629^{\star}$ & $0.845057^{\star}$ & $0.809088^{\star}$ & $0.762142^{\star}$ & -0.141334 & $0.692155^{\star}$ \\
\hline $\begin{array}{l}\text { Linkages \& } \\
\text { entrepreneurship }\end{array}$ & $0.768284^{\star}$ & $0.728448^{\star}$ & $0.693274^{\star}$ & $0.684159^{*}$ & -0.135411 & $0.539156^{\star}$ \\
\hline Intellectual assets & $0.599208^{\star}$ & $0.536921^{*}$ & $0.758261^{\star}$ & $0.700431^{\star}$ & -0.022346 & $0.617890^{*}$ \\
\hline Innovators & $0.743970^{*}$ & $0.535701^{*}$ & $0.631871^{\star}$ & $0.709978^{*}$ & -0.035266 & $0.222244^{*}$ \\
\hline
\end{tabular}

Note: Correlations at the level of significance $p<0.05, N=28$, significant correlations are marked with "*”.

Table 3. Indicators serving as weights in the index measuring the average level of innovativeness (source: own elaboration based on the data of the European Statistical Office - Eurostat)

\begin{tabular}{|c|c|c|c|}
\hline No. & Name of the indicator & Source & Top 10 countries according to 2016 \\
\hline 1 & \begin{tabular}{|l|} 
Persons employed in science and \\
technology as a percentage of active \\
population, age group considered \\
from 25 to 64 years [wst]
\end{tabular} & $\begin{array}{l}\text { Eurostat; } \\
2010-2016\end{array}$ & $\begin{array}{l}\text { Luxembourg, Sweden, Denmark, } \\
\text { Netherlands, Finland, Germany, United } \\
\text { Kingdom, Belgium, France, Austria }\end{array}$ \\
\hline 2 & \begin{tabular}{|l|} 
Scientists and engineers as a \\
percentage of active population, \\
age group considered from 25 to 64 \\
years old [wse]
\end{tabular} & $\begin{array}{l}\text { Eurostat; } \\
2010-2016\end{array}$ & $\begin{array}{l}\text { Sweden, United Kingdom, Finland, } \\
\text { Denmark, Netherlands, Ireland, Belgium, } \\
\text { Luxembourg, Germany, Slovenia }\end{array}$ \\
\hline 3 & $\begin{array}{l}\text { Research and development } \\
\text { personnel by sectors of } \\
\text { performance }\end{array}$ & $\begin{array}{l}\text { Eurostat; } \\
2010-2016\end{array}$ & \\
\hline $3 a$. & Total [wall] & $\begin{array}{l}\text { Eurostat; } \\
\text { 2010-2016 }\end{array}$ & $\begin{array}{l}\text { Denmark, Luxembourg, Finland, Sweden, } \\
\text { Austria, Belgium, Ireland, Germany, } \\
\text { Netherlands, France }\end{array}$ \\
\hline $3 \mathrm{~b}$. & Business Sector [wbs] & $\begin{array}{l}\text { Eurostat; } \\
2010-2016\end{array}$ & $\begin{array}{l}\text { Denmark, Sweden, Austria, Luxembourg, } \\
\text { Finland, Germany, Slovenia, Netherlands, } \\
\text { Belgium, France }\end{array}$ \\
\hline $3 c$. & Government Sector [wgs] & $\begin{array}{l}\text { Eurostat; } \\
2010-2016\end{array}$ & $\begin{array}{l}\text { Luxembourg, Slovenia, Bulgaria, Czech } \\
\text { Republic, Greece, Germany, Spain, France, } \\
\text { Netherlands, Lithuania }\end{array}$ \\
\hline $3 \mathrm{~d}$. & Higher Education Sector [whe] & $\begin{array}{l}\text { Eurostat; } \\
2010-2016\end{array}$ & $\begin{array}{l}\text { Ireland, Denmark, United Kingdom, } \\
\text { Finland, Portugal, Belgium, Estonia, } \\
\text { Greece, Sweden, Austria }\end{array}$ \\
\hline
\end{tabular}

Note: For easier identification, each of the variables acting as weights was assigned a code that was placed in square brackets next to the name of the variable. In the further part of the paper discussing the results of the statistical research, the authors mainly use the assigned variable codes. 
by a high percentage of research and development personnel employment. At the same time, in these countries, it is accompanied by a significant share of research and development personnel in the business sector. All the variables serving as weights with assigned names of countries which in a given area were characterised by the highest values of a given indicator are presented below (Table 3 ).

\section{Research methodology}

In this section, we propose an index of the average innovativeness change calculated for a group of countries. The main assumption states that the influence of data from the considered country on the total index value should be proportional to the employment share of a selected group of specialists (e.g.: scientists and engineers) in relation to the economically active population, i.e. working-age people who "generate" innovativeness. Firstly, we consider the case of two moments of observations $s$ and $t$ (see Section 3.1). As a consequence, Section 4.3 provides the generalisation of the previously proposed index into the case of many moments of observations, i.e. the generalised index measures the average innovativeness dynamics at the time interval $[s, t]$, and it takes into consideration all indirect moments $s+1, s+2, \ldots, t-1$. According to SII methodology, we assume that the unit time period equals one year and the proposed index provides the information about the average, one-year innovativeness change.

\subsection{Construction of the index of the average innovativeness change}

Let us consider a group of $N$-countries observed at discrete moments: $s$ and $t$, where $s$ is treated as the base time moment. Let us signify by $S I I_{i}^{\tau}$ the value of Summary Innovation Index calculated for the $i$-th country at time $\tau \in\{s, t\}$. Let us denote by $I_{j}^{s, t}$ the partial index of innovativeness change calculated for the $j$-th country and for time interval $[s, t]$ as follows

$$
I_{j}^{s, t}=\frac{S I I_{j}^{t}}{S I I_{j}^{s}}, j=1,2, \ldots, N .
$$

The procedure described below uses as an example one of the weights selected for the analysis, i.e. persons employed in science and technology as a percentage of active population. The analogous procedure applies to all the other weights analysed in the paper.

Let us denote by $n_{i}^{\tau}$ persons employed in science and technology as a percentage of active population of the $i$-th country at time $\tau \in\{s, t\}$ (the age group considered from 25 to 64 years). We treat each partial index $I_{j}^{s, t}$ as a random variable in some probability space $(\Omega, \mathfrak{J}, P)$ and we assume that the expected value and variance of $I_{j}^{s, t}$ are finite, i.e.

$$
I_{0 j}^{s, t}=E\left(I_{j}^{s, t}\right)<\infty, D^{2}\left(I_{j}^{s, t}\right)<\infty .
$$

We intend to find a vector of real weights $\left\{\gamma_{1}, \gamma_{2}, \ldots, \gamma_{N}\right\}$ to obtain the index of the average, one-period innovativeness change for the whole group of $N$ countries, i.e.

$$
I^{s, t}=\sum_{j=1}^{N} \gamma_{j} I_{j}^{s, t},
$$


where positive weights fulfil

$$
\sum_{j=1}^{N} \gamma_{j}=1
$$

Under the above significations and assumptions, the index $I^{s, t}$ is a random variable. Let us signify by $I_{0}^{s, t}$ its (finite) expected value, i.e. $I_{0}^{s, t}=E\left(I^{s, t}\right)$ and let us denote by $d I^{s, t}=I^{s, t}-I_{0}^{s, t}$. According to the standard statistical procedure in such cases, the problem of finding of weights $\left\{\gamma_{1}, \gamma_{2}, \ldots, \gamma_{N}\right\}$ can be limited to minimising dispersion of the index $I^{s, t}$. Our aim is to minimise

$$
\sigma_{I^{s, t}}^{2}=E\left(d I^{s, t}\right)^{2}=E\left(I^{s, t}-I_{0}^{s, t}\right)^{2}=E\left[\sum_{j=1}^{N} \gamma_{j}^{2}\left(I_{j}^{s, t}-I_{0 j}^{s, t}\right)^{2}\right] .
$$

Thus, we have the optimisation task where the objective function is

$$
F=\sum_{j=1}^{N} \gamma_{j}^{2} \sigma_{I_{j}^{s, t}}^{2},
$$

and the additional condition is described in (4). This optimisation task can be solved if we assume that $d I_{i}^{s, t}$ and $d I_{j}^{s, t}$ are independent random variables (Białek, 2007; Białek \& Czajkowski, 2008).

The essential and sufficient condition for the optimisation task defined by (4) and (6) is formulated as follows:

$$
\frac{\partial F}{\partial \gamma_{i}}=\frac{\partial F}{\partial \gamma_{k}}, \text { for each } i \text { and } k
$$

and that leads to the following consequence

$$
\gamma_{1} \sigma_{I_{1}^{s, t}}^{2}=\gamma_{2} \sigma_{I_{2}^{s, t}}^{2}=\ldots=\gamma_{N} \sigma_{I_{N}^{s, t}}^{2}
$$

From (4) and (8) we obtain that

$$
\gamma_{i}=\frac{1}{\sigma_{I_{i}^{s, t}}^{2}}\left(\sum_{j=1}^{N} \frac{1}{\sigma_{I_{j}^{s, t}}^{2}}\right)^{-1} .
$$

Let us denote by $S I I_{0 i}^{\tau}=E\left(S I I_{i}^{\tau}\right)$ for $\tau=s, t$. From the Taylor's theorem ${ }^{1}$, we have

$$
d I_{i}^{s, t} \approx \frac{d\left(S I I_{i}^{t}\right) S I I_{0 i}^{s}-S I I_{0 i}^{t} d\left(S I I_{i}^{s}\right)}{\left(S I I_{0 i}^{s}\right)^{2}}
$$

where

$$
d\left(S I I_{i}^{\tau}\right)=S I I_{i}^{\tau}-S I I_{0 i}^{\tau} \text {, for } \tau=s, t
$$

- ${ }^{1} \quad$ The approximation (10) can be obtained if we take into consideration the function $f(x, y)=$ $x / y$ and use its Taylor's approximation around the point $\left(x_{0}, y_{0}\right)$, i.e.

$$
\Delta f(x, y)=f(x, y)-f\left(x_{0}, y_{0}\right) \approx \frac{\partial f}{\partial x}\left(x_{0}, y_{0}\right)\left(x-x_{0}\right)+\frac{\partial f}{\partial y}\left(x_{0}, y_{0}\right)\left(y-y_{0}\right) .
$$

- $\quad$ Taking $(x, y)=\left(S I I_{i}^{t}, S I I_{i}^{s}\right)$ and $\left(x_{0}, y_{0}\right)=\left(S I I_{0 i}^{t}, S I I_{0 i}^{s}\right)$ we obtain (10). 
As a consequence, the variance of each partial of one-period innovativeness change can be calculated by

$$
\sigma_{I_{i}^{s, t}}^{2}=E\left(d I_{i}^{s, t}\right)^{2} \approx \frac{\left(S I I_{0 i}^{s}\right)^{2} \sigma_{S I I_{i}^{t}}^{2}+\left(S I I_{0 i}^{t}\right)^{2} \sigma_{S I I_{i}^{s}}^{2}}{\left(S I I_{0 i}^{s}\right)^{4}},
$$

where $\sigma_{S I I_{i}^{\tau}}^{2}$ denotes the variance of the Summery Innovation Index (treated as a random variable) calculated for the $i$-th country at time $\tau \in\{s, t\}$. Let us focus on the specific part of this variation connected with persons employed in science and technology aged from 25 to 64 years. Let us denote by $\tilde{\sigma}_{S I I_{i}^{\tau}}^{2}$ the part of total variance $\sigma_{S I I_{i}^{\tau}}^{2}$ which is proportional to the share of the above-mentioned persons employed in science and technology in active population, i.e.

$$
\tilde{\sigma}_{S I I_{i}^{\tau}}^{2}=n_{i}^{\tau} \sigma_{S I I_{i}^{\tau}}^{2}
$$

Let us assume that the corresponding volatility coefficients calculated for the considered moments $s$ and $t$ approximate each other, i.e.

$$
V_{i}^{s}=\frac{\tilde{\sigma}_{S I I_{i}^{s}}}{S I I_{0 i}^{s}} \approx V_{i}^{t}=\frac{\tilde{\sigma}_{S I I_{i}^{t}}}{S I I_{0 i}^{t}} .
$$

From (12) and (13) we obtain

$$
\sigma_{I_{i}^{s, t}}^{2} \approx \frac{\frac{\tilde{\sigma}_{S I I_{i}^{s}}^{2}}{\left(V_{i}^{s}\right)^{2}} \frac{\tilde{\sigma}_{S I I_{i}^{t}}^{2}}{n_{i}^{t}}+\frac{\tilde{\sigma}_{S I I_{i}^{t}}^{2}}{\left(V_{i}^{t}\right)^{2}} \frac{\tilde{\sigma}_{S I I_{i}^{s}}^{2}}{n_{i}^{s}}}{\frac{\tilde{\sigma}_{S I I_{i}^{s}}^{4}}{\left(V_{i}^{s}\right)^{4}}},
$$

and thus, taking the common signification for volatility coefficients $V_{i}^{0}$ (which is justified by (14)) we have

$$
\sigma_{I_{i}^{s, t}}^{2} \approx \frac{4}{H_{i}^{s, t}}\left(V_{i}^{0}\right)^{2} \frac{\tilde{\sigma}_{S I I_{i}^{t}}^{2}}{\tilde{\sigma}_{S I I_{i}^{s}}^{2}}
$$

where $H_{i}^{s, t}$ denotes the harmonic mean of $n_{i}^{s}$ and $n_{i}^{t}$, i.e.

$$
H_{i}^{s, t}=\frac{2}{\frac{1}{n_{i}^{s}}+\frac{1}{n_{i}^{t}}} .
$$

Using (14) we can express the approximation (16) as follows

$$
\sigma_{I_{i}^{s, t}}^{2} \approx \frac{4}{H_{i}^{s, t}}\left(V_{i}^{0}\right)^{2} \frac{\tilde{\sigma}_{S I I_{i}^{t}}^{2}}{\tilde{\sigma}_{S I I_{i}^{s}}^{2}} \frac{\left(S I I_{0 i}^{s}\right)^{2}\left(S I I_{0 i}^{t}\right)^{2}}{(S)^{2}\left(S I I_{0 i}^{s}\right)^{2}} \approx \frac{4}{H_{i}^{s, t}}\left(V_{i}^{0}\right)^{2}\left(\frac{S I I_{0 i}^{t}}{S I I_{0 i}^{s}}\right)^{2} .
$$

From (9) and (18) we have the final conclusion about the harmonic structure of weights, i.e. we can use

$$
\gamma_{i}=\frac{2}{\frac{1}{n_{i}^{s}}+\frac{1}{n_{i}^{t}}}\left(\sum_{j=1}^{N} \frac{2}{\frac{1}{n_{j}^{s}}+\frac{1}{n_{j}^{t}}}\right)^{-1},
$$


and thus, the index $I^{s, t}$ can be expressed as follows

$$
I^{s, t}=\left(\sum_{j=1}^{N} \frac{2}{\frac{1}{n_{j}^{s}}+\frac{1}{n_{j}^{t}}}\right)^{-1} \cdot \sum_{j=1}^{N} \frac{2}{\frac{1}{n_{j}^{s}}+\frac{1}{n_{j}^{t}}} \cdot \frac{S I I_{j}^{t}}{S I I_{j}^{s}} .
$$

The interpretation of index (20) is as follows: for instance, the value $I^{s, t}=1.02$ obtained for the European Union indicates that the level of innovativeness (measured by the SII) of the whole group of EU countries increased by $2 \%$ (average) comparing two time moments $s$ and $t$.

\subsection{Index for the time interval}

Before we propose an index of the average innovativeness change for the time interval case, we would like to present several postulates for the proper definition of such indices. The index of the average year-on-year innovativeness change $I(s, t)$ should satisfy:

\section{Postulate 1}

$$
\forall j \in\{1,2, \ldots, N\} \quad \forall \tau \in\{s+1, s+2, \ldots, t\} \quad I_{j}^{\tau-1, \tau}=1 \Rightarrow I(s, t)=1 .
$$

This postulate says that in the case when partial indices show no change of innovativeness level during each yearly period, then the global index must inform us about no change of innovativeness level of the group at the whole considered time interval.

\section{Postulate 2}

The influence of individual countries on the one-period change in the level of innovativeness of the entire group of countries is the smaller, the smaller the employment share of a selected group of specialists (e.g.: scientists and engineers) in relation to the economically active population in a given country.

\section{Postulate 3}

If all partial indices of innovativeness change $\left(I_{j}^{\tau-1, \tau}\right)$, increase (decrease) by $m \%$, then the value of global index $I(s, t)$ will also increase (decrease) by $m \%$.

\section{Postulate 4}

If the employment share of a selected group of specialists (e.g.: scientists and engineers) in relation to the economically active population in each country increases (decreases) by about the same $m \%$ at considered time moments, then the index $I(s, t)$ will not change.

\section{Postulate 5}

If we limit the study to 2 moments of observations $s$ and $t$, then the index $I(s, t)$ will be reduced to the index $I^{s, t}$.

Our proposition of a global index of the average innovativeness change calculated for a group of countries and for time interval $[s, t]$ is as follows:

$$
I(s, t)=\sum_{i=1}^{N} \beta_{i} \cdot \sum_{\tau=s+1}^{t} \alpha_{i}(\tau) \cdot I_{i}^{\tau-1, \tau},
$$

where 


$$
\begin{gathered}
\beta_{i}=\frac{\frac{1}{\sum_{\tau=s}^{t} \frac{1}{n_{i}^{\tau}}}}{\sum_{j=1}^{N} \frac{1}{\sum_{\tau=s}^{t} \frac{1}{n_{j}^{\tau}}}} \\
\alpha_{i}(\tau)=\frac{\frac{2}{\sum_{i}^{\tau-1}+\frac{1}{n_{i}^{\tau}}}}{\sum_{m=s+1}^{t} \frac{1}{n_{i}^{m-1}}+\frac{1}{n_{i}^{m}}} .
\end{gathered}
$$

It is easy to verify that $\beta_{i}$ and $\alpha_{i}(\tau)$ play the role of weights, i.e.

$$
\sum_{j=1}^{N} \beta_{j}=1, \sum_{\tau=s+1}^{t} \alpha_{i}(\tau)=1 .
$$

It can be proven (the proof is omitted) that the index $I(s, t)$ satisfies postulates $1-5$. In particular, for two moments of observations, we have: $\beta_{j}=\gamma_{j}, \alpha_{i}(\tau)=1$ and $I(s, t)=I^{s, t}$. The interpretation of index (22) is as follows: for instance, the value $I(s, t)=1.02$ obtained for the European Union indicates that between time moments $s$ and $t$ an average year-on-year increase by $2 \%$ in the level of innovativeness (measured by the SII) of the whole group of EU countries was noticed.

\section{Empirical study}

We apply the above-presented formula of the global index $I(s, t)$ in the analysis of innovativeness dynamics of the whole European Union (EU-28 group), EU-15 group, EU-13 group and V-4 group in the years 2010-2016. We also consider several three-year subintervals, i.e. 2010-2013, 2011-2014, 2012-2015 and 2013-2016. Tables 1-4 present the average innovativeness change calculated for the above-mentioned group of countries and considered time subintervals. The one-year innovativeness changes depending on the system of weights and calculated for the same group of countries are presented in Figures 1-4. We take into consideration the weights discussed in Section 2, wst, wse, wall, wbs, whe, including wgs.

The conducted analysis indicates that among the three-year time periods considered the dynamics of changes in innovativeness was negative in the years 2011-2014, i.e. in the period in which the index $I(s, t)$ for all the weights had the values of less than 1 . Considering the entire time period of 2010-2016, we can see that the average one-year dynamics of changes in the level of innovativeness of the group, i.e. the entire EU, was at the level ranging from $0.44 \%$ (wgs weight) to $0.8 \%$ (whe weight). The smallest index values, regardless of the time interval, were obtained for the wgs weight. However, due to the low level of correlation of this weight with the Summary Innovation Index values (see Table 2), the results for wgs 
Table 4. The average innovativeness change $I(s, t)$ calculated for the EU-28 (source: own elaboration based on the data of the European Statistical Office - Eurostat and European Commission, 2018. European Innovation Scoreboard 2018)

\begin{tabular}{|c|c|c|c|c|c|}
\hline \multirow{2}{*}{ Weights } & \multicolumn{5}{|c|}{ Time periods (years) } \\
\cline { 2 - 6 } & $2010-2013$ & $2011-2014$ & $2012-2015$ & $2013-2016$ & $2010-2016$ \\
\hline wst & 1.00247 & 0.99560 & 1.00947 & 1.01060 & 1.00659 \\
\hline wse & 1.00081 & 0.99363 & 1.00767 & 1.01086 & 1.00599 \\
\hline wall & 1.00361 & 0.99684 & 1.00782 & 1.01049 & 1.00717 \\
\hline wbs & 1.00496 & 0.99929 & 1.00734 & 1.00967 & 1.00743 \\
\hline wgs & 0.99966 & 0.98990 & 1.00692 & 1.00918 & 1.00446 \\
\hline whe & 1.00341 & 0.99611 & 1.00890 & 1.01235 & 1.00800 \\
\hline
\end{tabular}
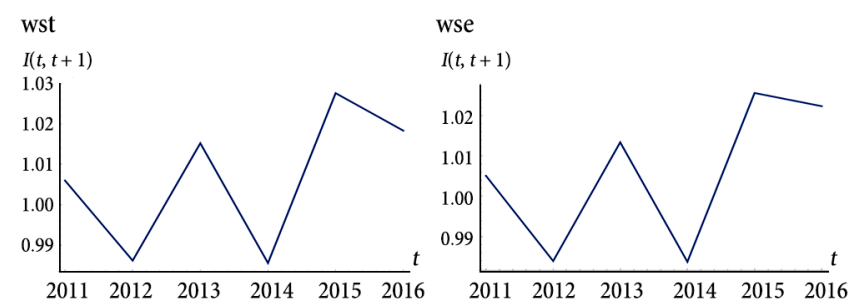

wall

$I(t, t+1)$
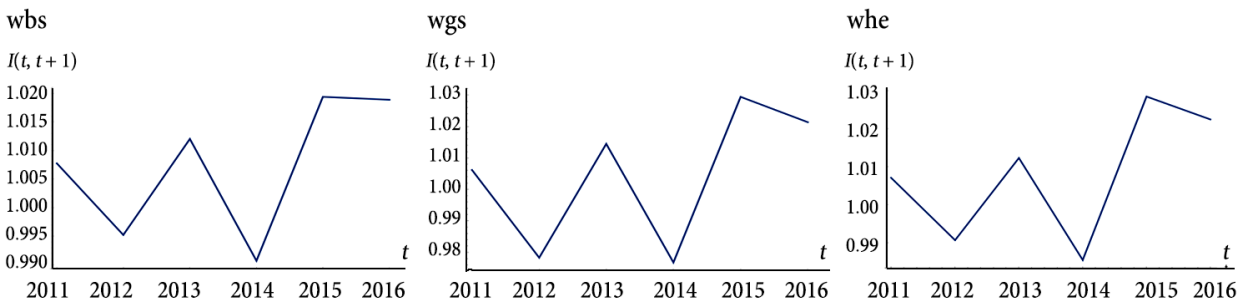

Figure 1. The one-year innovativeness changes depending on the system of weights and calculated for the EU-28 (source: own elaboration based on the data of the European Statistical Office - Eurostat and European Commission, 2018. European Innovation Scoreboard 2018)

should be treated with some caution. The analysis of changes in the level of innovativeness for annual intervals (see Figure 1) indicates that these changes are characterised by a high level of fluctuations and do not show a clear time trend.

The highest dynamics of changes in the level of innovativeness of the group of EU-15 countries was observed in the period 2013-2016 and the lowest in 2011-2014 (Table 5), when - similarly as in the case of the entire EU (see Table 4) - the analysed index had the values of less than 1 . Considering the entire time period of 2010-2016, we can see that the average one-year dynamics of changes in the level of innovativeness of the EU-15 group was at the level ranging from $0.65 \%$ ( $w g s$ weight) to $0.8 \%$ ( $w b s$ weight). Again, the smallest values of the index were obtained for the wgs weights, and this time the largest ones for the $w b s$ weights. The analysis of changes in the level of innovativeness for annual intervals (see Figure 2) leads to the conclusion that these changes are characterised by a lower level of fluctuations 
Table 5. The average innovativeness change $I(s, t)$ calculated for the EU-15 (source: own elaboration based on the data of the European Statistical Office - Eurostat and European Commission, 2018. European Innovation Scoreboard 2018)

\begin{tabular}{|c|c|c|c|c|c|}
\hline \multirow{2}{*}{ Weights } & \multicolumn{5}{|c|}{ Time periods (years) } \\
\cline { 2 - 6 } & $2010-2013$ & $2011-2014$ & $2012-2015$ & $2013-2016$ & $2010-2016$ \\
\hline wst & 1.00592 & 0.99767 & 1.00236 & 1.00899 & 1.00743 \\
\hline wse & 1.00441 & 0.99682 & 1.00215 & 1.01040 & 1.00746 \\
\hline wall & 1.00605 & 0.99737 & 1.00210 & 1.00882 & 1.00747 \\
\hline wbs & 1.00713 & 0.99894 & 1.00244 & 1.00890 & 1.00804 \\
\hline wgs & 1.00802 & 0.99514 & 1.00022 & 1.00497 & 1.00652 \\
\hline whe & 1.00372 & 0.99537 & 1.00196 & 1.00966 & 1.00684 \\
\hline
\end{tabular}
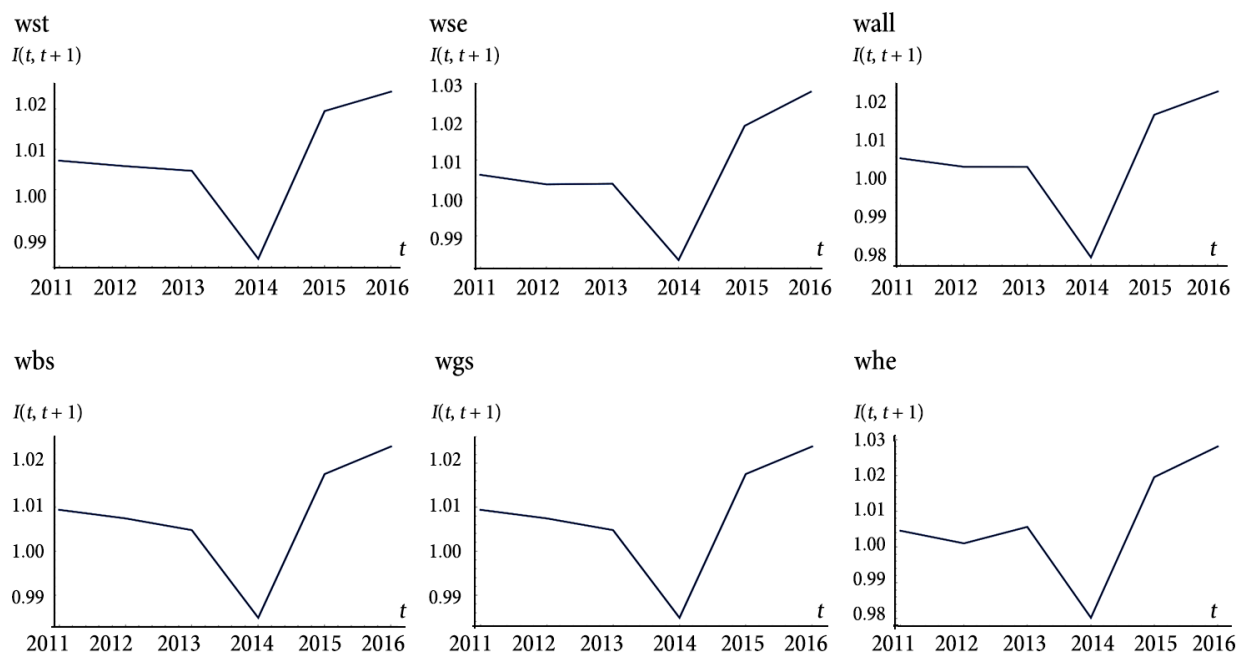

Figure 2. The one-year innovativeness changes depending on the system of weights and calculated for the EU-15 (source: own elaboration based on the data of the European Statistical Office - Eurostat and European Commission, 2018. European Innovation Scoreboard 2018)

than in the entire EU and an upward trend from 2014 onwards.

In the case of the group of countries referred to as EU-13 (Table 6), the highest increase in the level of innovativeness was recorded in the years 2012-2015. In the years 2010-2013 and 2011-2014, however, the dynamics of innovativeness of the EU-13 was characterised by a downward trend, and the analysed index had the values of less than 1. Taking into consideration the entire time period of 2010-2016, we can see that the average one-year dynamics of changes in the level of innovativeness of the EU-13 group was at the level ranging from $0.21 \%$ (wgs weight) to as much as $1.02 \%$ (whe weight). The analysis of changes in the level of innovativeness for annual intervals (see Figure 3) leads to the conclusion that these changes are characterised by noticeable fluctuations, however, despite the registered drop in the oneyear dynamics of innovativeness for 2016, they seem to have an upward trend.

Based on the results shown in Table 7, we observe that the 2012-2015 period was the 
best period in terms of dynamics of innovativeness among the analysed periods for the V4 countries. The worst, on the other hand, from the point of view of changes in the level of innovativeness, were the years 2010-2013 and 2011-2014, which is similar to the situation in the EU-13 group. Considering the entire time period of 2010-2016, we can see that the average one-year dynamics of changes in the level of innovativeness of the EU-15 group was at the level ranging from $-0.17 \%$ (a drop for the $w g s$ weight) to $0.39 \%$ (a slight increase for the whe weight). In general, the situation in this group of countries is the worst in terms of the increase in the level of innovativeness in the years 2010-2016. The analysis of changes in the level of innovativeness for annual intervals (see Figure 4) leads to the conclusion that these changes are characterised by a lower level of fluctuations than in the entire EU, and despite the recorded decline in one-year dynamics of innovativeness for 2016, they seem to show an upward trend (excluding the whe weight, where it is difficult to observe any trend).

Table 6. The average innovativeness change $I(s, t)$ calculated for the EU-13 (source: own elaboration based on the data of the European Statistical Office - Eurostat and European Commission, 2018. European Innovation Scoreboard 2018)

\begin{tabular}{|c|c|c|c|c|c|}
\hline \multirow{2}{*}{ Weights } & \multicolumn{5}{|c|}{ Time periods (years) } \\
\cline { 2 - 6 } & $2010-2013$ & $2011-2014$ & $2012-2015$ & $2013-2016$ & $2010-2016$ \\
\hline wst & 0.99744 & 0.99253 & 1.02000 & 1.01299 & 1.00536 \\
\hline wse & 0.99473 & 0.98825 & 1.01681 & 1.01160 & 1.00354 \\
\hline wall & 0.99814 & 0.99569 & 1.02055 & 1.01421 & 1.00649 \\
\hline wbs & 0.99794 & 1.00039 & 1.02218 & 1.01196 & 1.00550 \\
\hline wgs & 0.99033 & 0.98396 & 1.01459 & 1.01395 & 1.00216 \\
\hline whe & 1.00285 & 0.99749 & 1.02240 & 1.01775 & 1.01023 \\
\hline
\end{tabular}
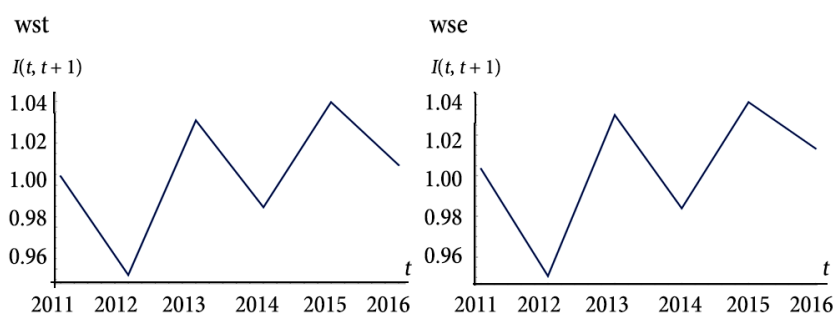

wall

$\begin{array}{llllll}2011 & 2012 & 2013 & 2014 & 2015 & 2016\end{array}$
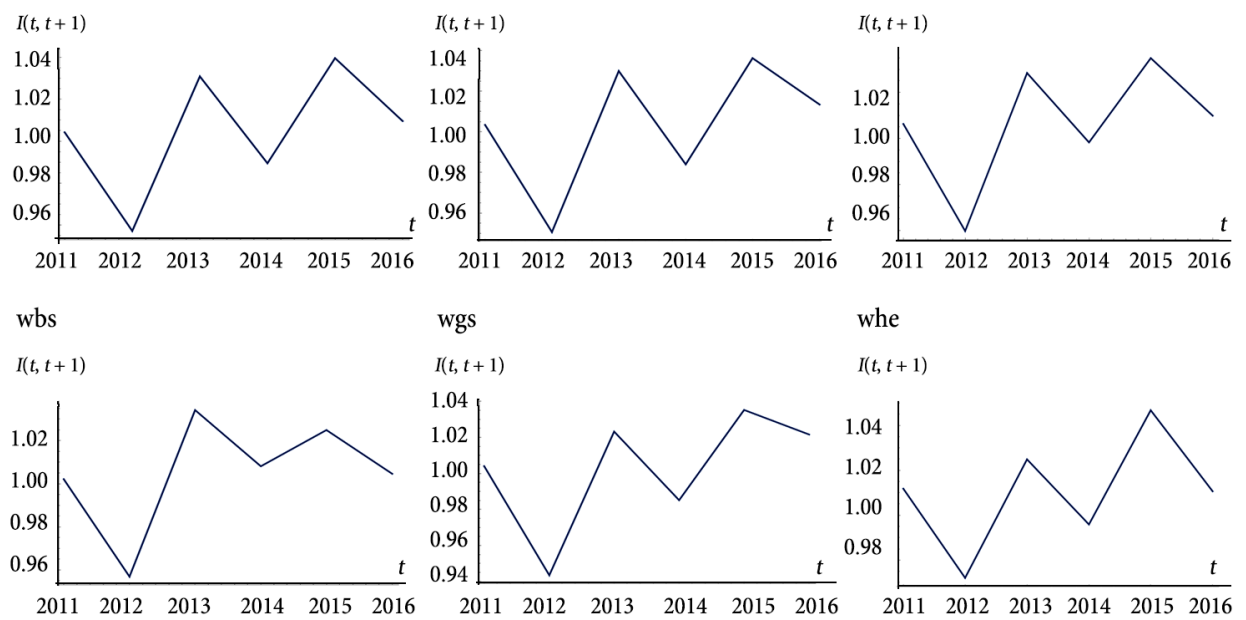

whe

$I(t, t+1)$

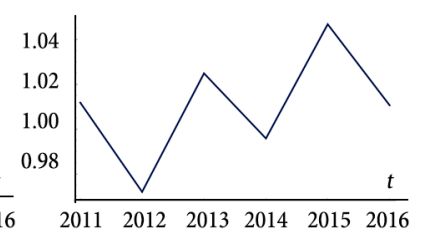

Figure 3. The one-year innovativeness changes depending on the system of weights and calculated for the EU-13 (source: own elaboration based on the data of the European Statistical Office - Eurostat and European Commission, 2018. European Innovation Scoreboard 2018) 
Table 7 . The average innovativeness change $I(s, t)$ calculated for the V-4 (source: own elaboration based on the data of the European Statistical Office - Eurostat and European Commission, 2018. European Innovation Scoreboard 2018)

\begin{tabular}{|c|c|c|c|c|c|}
\hline \multirow{2}{*}{ Weights } & \multicolumn{5}{|c|}{ Time periods (years) } \\
\cline { 2 - 6 } & $2010-2013$ & $2011-2014$ & $2012-2015$ & $2013-2016$ & $2010-2016$ \\
\hline wst & 0.99667 & 0.98812 & 1.00768 & 1.00738 & 1.00212 \\
\hline wse & 0.99386 & 0.98663 & 1.00823 & 1.00862 & 1.00174 \\
\hline wall & 0.99459 & 0.98824 & 1.00819 & 1.00660 & 1.00089 \\
\hline wbs & 0.98726 & 0.98704 & 1.00919 & 1.00767 & 0.99833 \\
\hline wgs & 0.99487 & 0.98790 & 1.00803 & 1.00637 & 1.00073 \\
\hline whe & 1.00286 & 0.99001 & 1.00690 & 1.00512 & 1.00398 \\
\hline
\end{tabular}
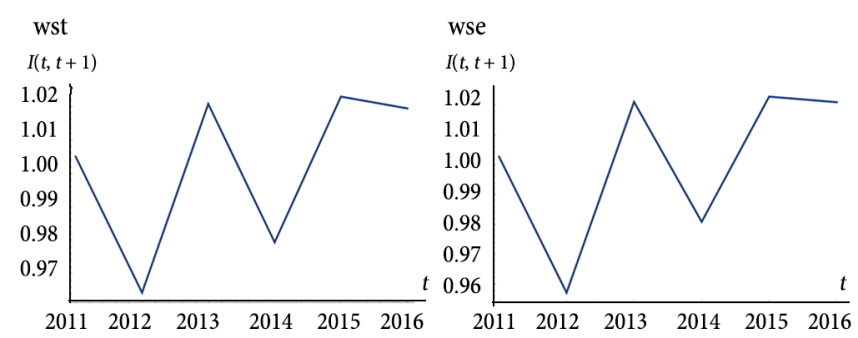

wall
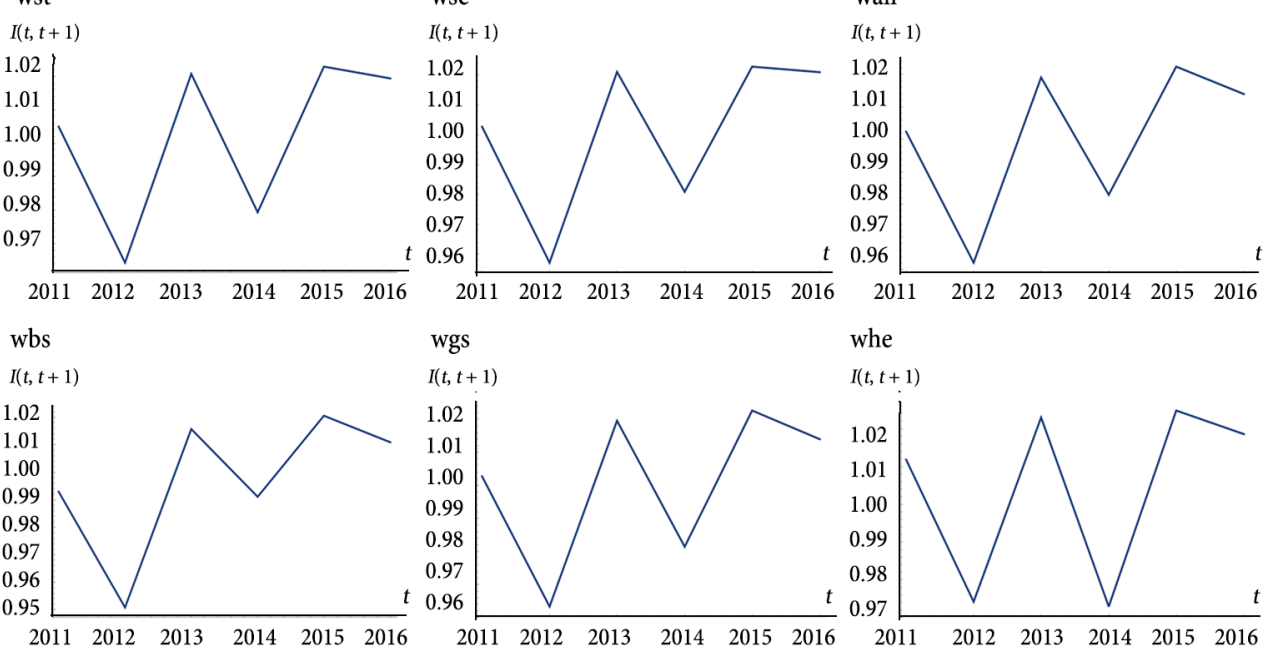

Figure 4. The one-year innovativeness changes depending on the system of weights and calculated for the V-4 (source: own elaboration based on the data of the European Statistical Office - Eurostat and European Commission, 2018. European Innovation Scoreboard 2018)

\section{Discussion}

In the context of the conducted analyses, one should bear in mind the significant aggregation of data, making it difficult to capture the existing dependencies at the level of an individual country. First of all, the object of the analysis is synthetic in its nature and its value is the resultant of as many as 27 individual indices, and the subject of the analysis consists of selected groups of countries, including the EU-28, EU-15, EU-13 and the Visegrad Group - V4. Nevertheless, in the discussion on the results obtained, it is worth noting three issues that explain the applicability of the conducted analyses.

(1) In the examined period of time, some regularities can be observed between the level of innovativeness expressed through the Summary Innovation Index and the adopted weight 
system. It can be concluded that innovation performance in the EU Member States reflects in a particular manner the participation of research and development personnel in the private sector in labour force. There is a strong positive relationship between the share of research and development personnel in the private sector and the level of SII. Based on the results of the study conducted for the EU Member States, it should be assumed that innovation performance is supported by a high private sector participation in $\mathrm{R} \& \mathrm{D}$ expressed by the percentage of employees. An equally positive impact on the level of innovativeness of the economy can be observed due to the participation of the private sector in the financing of R\&D (Savrul \& Incekara, 2015), which is one of the variables included in the Summary Innovation Index. The adopted weight system works to a large extent in favour of more technologically advanced countries, hence those in which already innovation performance is high. Therefore, the analysis covering the entire examined period of time is the most favourable for the EU-15.

(2) The lags described in the literature between expenditure on research and development and innovative activity along with its market effects are also observed in the values of the presented index. Measurement of innovation under the European Innovation Scoreboard is in close relation with the EU policy in the field of supporting and stimulating innovative activity of enterprises and public institutions (private and public sector). The innovation policy is a link between the policy of research and technological development and the industrial policy. It allows for creating conditions conducive to the introduction of ideas into the market. The effects of the innovation policy being created by the governmental agencies, including the EU institutions, are reflected in the distribution of funds for innovative activity through various assistance programmes financed from the EU budget. The analysis presented in the paper in particular refers to the programming period covering the years 2007-2013, in which period in accordance with the $\mathrm{N}+2$ rule, the settlement of the funds spent was completed by the end of 2015. Announcing competitions under assistance programmes financed from the EU budget requires legally binding implementing documents. Therefore, most often the distribution of funds follows after a yearly and sometimes even two-year delay. This translates directly into periods of intensification of innovative activity carried out by private and public institutions benefiting from the EU support. This intensification of innovative activity can be observed directly in Tables 6 and 7. Both in the case of the EU-13 and the Visegrad Group, the level of innovativeness in these countries changed most dynamically in 2012-2015 and 2013-2016, with some predominance for the period 2012-2015.The EU policy, including the distribution of assistance funds, is aimed at reducing disparities between its Member States, including ones in the area of innovativeness. Therefore, the most important recipients of these funds are those countries in which the level of innovativeness is significantly lower than the EU average. In this context, the proposed index can be used to assess the effectiveness of implementation of individual financial instruments conducive to development and to stimulate innovativeness by measuring the medium-term dynamics of changes made at selected time intervals.

Regardless of the analysed aggregate, the EU-28, EU-15, EU-13 or the V4 Group, in relation to all the analysed periods, the dynamics of innovation performance is the highest in the years 2013-2016. This is clearly part of the scientific argument about the occurrence of lags in the measurement of the relationship between expenditure on innovation and development borne by enterprises and the resulting effects of this activity (see Hall, Griuches, \& 
Hausman, 1986; Vancauteren, Melenberg, Plasmans, \& Bongard, 2017). Investing in R\&D is a dynamic process due to the fact that the company must incur costs in the present period for an anticipated gain in profits in the future, which explains the possible time lag in the R\&D-innovation-productivity relationship (Roberts \& Vuong, 2013). According to Raymond, Mairesse, Mohnen, and Palm (2015), when assessing persistence of innovation, the lag effect refers to two to four years when the incidence of product innovation is considered and to four years when the share of innovative sales is taken into account. For example, empirical studies conducted based on the example of the Polish economy, or more precisely, on the basis of its manufacturing divisions, have shown that the impact of $R \& D$ expenditure on gross value added may only become apparent after some time - in some cases, no sooner than 2 years after costs incurred. It is impossible to immediately implement the solutions developed, and thus translate them into a real improvement of companies' operations. In addition, the value of production sold is significantly affected by expenditure on innovations that has been delayed by one period (Witkowski \& Weresa, 2006, pp. 208-210).

(3) As the saturation level increases, the dynamics of changes within the analysed index decreases. The rate of growth of economic indices, but also social indices, after reaching a certain threshold value, begins to slow down. Economic indices are subject to cyclical amplitude. Therefore, maintaining the growth trajectory often means the need to reduce the growth rate within a given index (Jones, 2016, pp. 3-69). This is also reflected in the results presented in individual Tables from 4 to 7 . Namely, taking into account any of the fouryear sub-periods distinguished, the dynamics of changes in the innovation performance of the EU-28, and especially the EU-15, is much smaller than the dynamics of changes in the EU-13 countries and the V4 countries. From the point of view of the Summary Innovation Index methodology, all representatives of the Visegrad Group as well as the vast majority of EU-13 Member States are in the moderate innovators group, which results from the fact that their innovation performance is between $50 \%$ and $90 \%$ of the EU average. Consequently, a comparison of the values of particular individual measures constituting the SII indicates the existence of significant differences between the EU-13 representatives (countries) and the EU-15 representatives (countries). Therefore, in the EU-13 countries as well as in the Visegrad Group, there is still room for generating a high rate of change within individual indices.

The effects of lags and the slowdown in the growth rate of economic indices after reaching certain thresholds (the arguments described in points (2) and (3) above) are more important and are easier to observe for shorter time intervals, up to three or four years. Therefore, in the case of analyses covering the whole analysed period 2010-2016, the dynamics of changes in innovation performance will be the best for the countries representing mainly the EU-15 (see Table 5 and Table 8). It should be taken into account that in most of the EU countries, also those being innovation leaders, there is still room for generating increases within individual indices, even if the rate of growth is slowing down. In this situation, the extension of the time series works in favour of analyses carried out for the EU-15 countries.

The proposed global index of the one-period dynamics of innovativeness is a doubly weighted arithmetic mean of partial indices of one-period changes in the level of innovativeness of the countries forming the aggregate. In the presented index, it is possible to resign from weights by accepting that each country in each year of analysis has an identical 
share in creating the average dynamics of innovativeness in the entire group of countries. In other words, the abandonment of the weighing system means in practice the adoption of time-constant and equal weights, which, according to the authors, may lead to distortions in the assessment of the average level of changes in the phenomenon of innovativeness over time. The system of double weights not only results from the adopted postulates, which in the opinion of the authors a well-constructed index of this type should meet, but also has its substantive justification. One type of weights reflects the size of a given country's share in creating changes in the group's innovativeness throughout the entire period considered. Whereas, the other type of weights reflects the analogical share of a given country for the two selected adjacent periods (years) of analysis. Thus, the other system of weights is focused on the study of changes in the impact of individual members of the analysed group of countries when moving from one year of analysis to the next. Thanks to the double weight system, the global index seems to be more "fair" and more accurate, especially since the expert selection of weights was based on both substantive and statistical premises. The analysis includes only those intuitively relevant weights whose level of correlation with the variable (index) denoting innovativeness was appropriately high.

Let us note that the choice of the system of weights for the calculation of the index $I(s, t)$ influences the final results (see Tables 1-4). In particular, as a rule, the whe or wbs weights (the higher education system and the business sector respectively) lead to higher index values, while the wgs weights (the government sector) lead to smaller index values. Considering the entire time period of 2010-2016 and on the basis of the results from Tables from 4 to 7, we can state that innovativeness in the case of the EU-15 countries shows the best dynamics compared to other groups of countries, while the situation among the V-4 countries is the worst (for any system of weights). Thus, the main hypothesis, stating that the dynamics of the level of innovativeness of the entire EU (both on an annual basis and within any comparable time interval) differs from the analogical assessment of a selected subgroup (e.g.: the EU 13, EU 15, V4), formulated in the Introduction, has been confirmed. It is also worth noting that the presented index formula can also be used to analyse the dynamics of changes in the level of innovativeness of a single country, which is then considered a one-element "group". Table 8 presents the values of the analysed index for each of the EU countries individually for two selected periods of time: 2010-2016 and 2013-2016 (the wall weight was taken into account). A graphic presentation of these results, reflecting the diversity of EU countries in terms of the annual dynamics of changes in their level of innovativeness, is shown in Figure 5. It can be seen that the most dynamic countries (in terms of changes in the level of innovativeness) are Lithuania (5.9\% average increase in the years 2010-2016; 9.3\% average increase in the years 2013-2016), Latvia (3.8\% average increase in the years 2010-2016; 9.5\% average increase in the years 2013-2016), Malta (2.7\% average increase in the years 2010-2016; 3.0\% average increase in the years 2013-2016) and the United Kingdom (2.2\% average increase in the years 2010-2016; 5.2\% average increase in the years 2013-2016). It is worth noting that the comparison of the dynamics of changes in the level of innovativeness for individual countries shows that out of the thirteen countries that joined the EU structures after 2004, nine recorded a higher level of average innovativeness growth in the years 2013-2016 than in the entire analysed period. 
Table 8. The average one-year innovativeness change $I(s, t)$ calculated for the EU countries for the interval 2010-2016 and 2013-2016 (source: own elaboration based on the data of the European Statistical Office - Eurostat and European Commission, 2018. European Innovation Scoreboard 2018)

\begin{tabular}{|c|c|c|c|c|c|c|c|c|c|c|c|}
\hline \multirow[b]{2}{*}{ 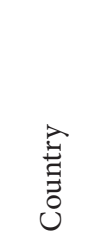 } & \multicolumn{2}{|c|}{ Index value } & \multirow[b]{2}{*}{ 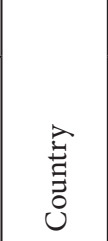 } & \multicolumn{2}{|c|}{ Index value } & \multirow[b]{2}{*}{ 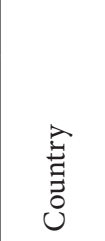 } & \multicolumn{2}{|c|}{ Index value } & \multirow[b]{2}{*}{ 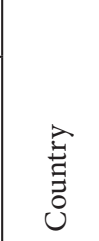 } & \multicolumn{2}{|c|}{ Index value } \\
\hline & $\begin{array}{l}0 \\
\stackrel{0}{1} \\
i \\
\vdots \\
0 \\
\stackrel{i}{1}\end{array}$ & $\begin{array}{l}0 \\
\ddot{1} \\
i \\
\\
\ddot{i}\end{array}$ & & $\begin{array}{l}0 \\
\stackrel{1}{1} \\
i \\
\vdots \\
0 \\
\stackrel{i}{1}\end{array}$ & $\begin{array}{l}0 \\
\stackrel{1}{0} \\
i \\
n \\
\stackrel{i}{0}\end{array}$ & & 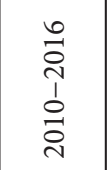 & 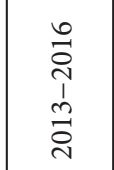 & & 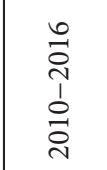 & 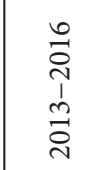 \\
\hline $\begin{array}{l}\text { Bel- } \\
\text { gium }\end{array}$ & 1.00816 & 1.01458 & Greece & 0.99808 & 0.99276 & $\begin{array}{l}\text { Lith- } \\
\text { uania }\end{array}$ & 1.05983 & 1.09294 & $\begin{array}{l}\text { Por- } \\
\text { tugal }\end{array}$ & 0.9931 & 0.99483 \\
\hline $\begin{array}{l}\text { Bul- } \\
\text { garia }\end{array}$ & 1.00139 & 1.03975 & Spain & 1.00574 & 1.00877 & \begin{tabular}{|l|} 
Lu- \\
xem- \\
bourg
\end{tabular} & 1.01306 & 0.99915 & $\begin{array}{l}\text { Ro- } \\
\text { mania }\end{array}$ & 0.94317 & 0.93844 \\
\hline $\begin{array}{l}\text { Czech } \\
\text { Re- } \\
\text { public }\end{array}$ & 0.9901 & 1.00181 & France & 1.01612 & 1.02875 & $\begin{array}{l}\text { Hun- } \\
\text { gary }\end{array}$ & 0.99589 & 1.01155 & $\begin{array}{l}\text { Slo- } \\
\text { venia }\end{array}$ & 1.00314 & 1.00667 \\
\hline $\begin{array}{l}\text { Den- } \\
\text { mark }\end{array}$ & 1.00117 & 0.98798 & Croatia & 0.99695 & 1.00193 & Malta & 1.02723 & 1.03025 & $\begin{array}{l}\text { Slo- } \\
\text { vakia }\end{array}$ & 1.01878 & 0.99609 \\
\hline $\begin{array}{l}\text { Ger- } \\
\text { many }\end{array}$ & 0.99555 & 0.98823 & Italy & 1.00339 & 1.01115 & $\begin{array}{l}\text { Ne- } \\
\text { ther- } \\
\text { lands }\end{array}$ & 1.01526 & 1.00743 & $\begin{array}{l}\text { Fin- } \\
\text { land }\end{array}$ & 1.00109 & 1.00452 \\
\hline Estonia & 0.99151 & 0.96215 & Cyprus & 0.9796 & 0.95627 & Austria & 1.01424 & 1.0103 & $\begin{array}{l}\text { Swe- } \\
\text { den }\end{array}$ & 1.00596 & 1.00424 \\
\hline Ireland & 1.01572 & 1.04029 & Latvia & 1.03857 & 1.09507 & Poland & 1.0077 & 1.02039 & $\begin{array}{l}\text { United } \\
\text { King- } \\
\text { dom }\end{array}$ & 1.02151 & 1.05217 \\
\hline
\end{tabular}

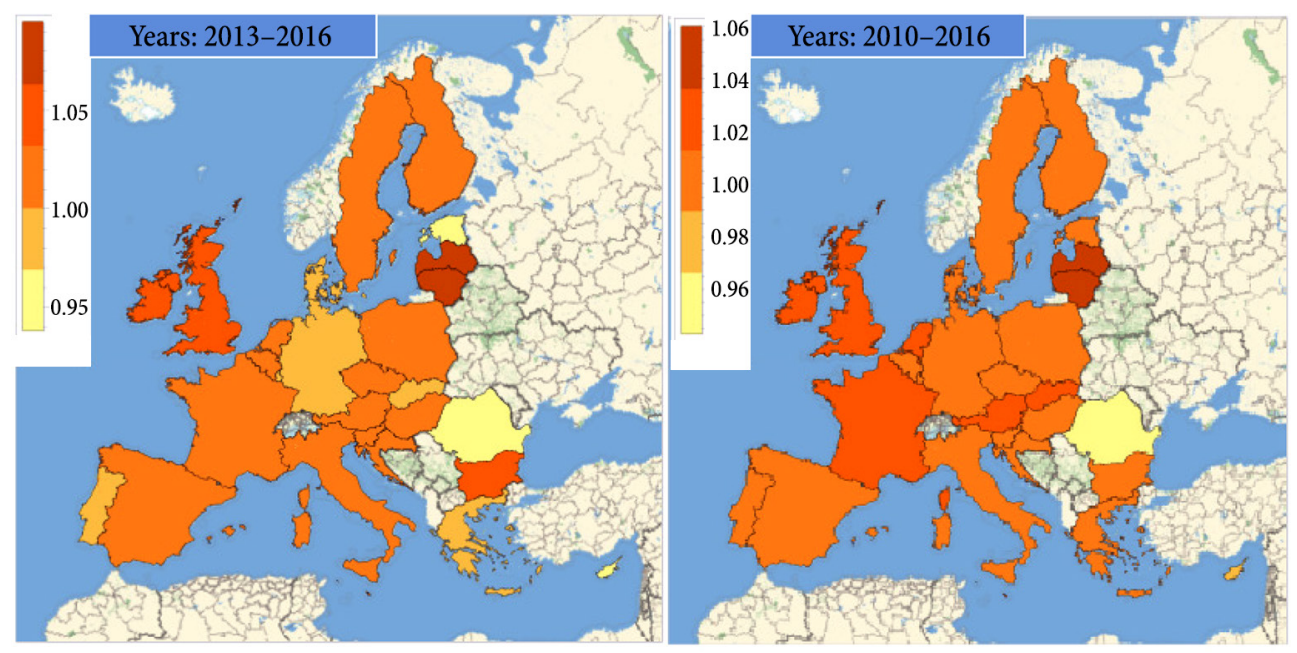

Figure 5. The one-year innovativeness changes in the EU countries for two selected time periods (source: own elaboration based on the data of the European Statistical Office - Eurostat and European Commission, 2018. European Innovation Scoreboard, 2018) 


\section{Conclusions}

Innovation indices presented in the paper seem to be well-constructed and quite universal. The first one is designed to compare two observation moments and its construction results from minimising its dispersion, which ensures small estimation errors. The other index is a generalisation of the first index into the case of the time interval, i.e. the case in which we take into account more than two time moments. The proposal of the other index was based on economically and intuitively valid postulates, which corresponds to the axiomatic theory of indices. The presented postulates should be treated as a kind of list of minimum requirements for this type of measure, which is a certain equivalent of the so-called minimum requirements in the index theory (cf. Martini, 1992). Both indices are reliable - they allow to assess the average, one-period innovation performance dynamics over a given period of time. The values of indices are easy to interpret as illustrated by the empirical study presented in the paper. Higher values of the calculated indices testify to higher dynamics of changes in the level of innovativeness, which is a reflection of a situation more desirable in practice. The universality of the proposed indices is threefold. Firstly, although the analyses in the presented study are based on the Summary Innovation Index, they can in general be based on any innovation index or measure generating nominal values, if only this measure evaluates innovativeness. Secondly, the paper includes some subjectively selected weight systems which in the opinion of the authors, and also after preliminary statistical analyses, seemed to best reflect the employment share of a selected group of specialists (e.g.: scientists and engineers) in relation to the economically active population. However, a researcher using the indices proposed in the paper has virtually a free choice of weights. Thirdly, although the indices were meant to assess the innovation performance dynamics of a group of countries (such as the EU or V4), from a technical point of view, there is nothing to prevent the use of these indices to assess only one selected country. In this case, the formula is reduced to a single weighted arithmetic mean of partial indices, and thus differs from geometric mean, which is usually used in such homogeneous groups (more precisely, it is then the geometric mean of chain indices determined for adjacent time moments). However, the advantage of the proposed measures is that, unlike chain indices or geometric mean, they are ideal for studying changes over time in the level of a phenomenon for a certain aggregate consisting of a group of objects (countries). In conclusion, it should be assumed that the empirical study carried out in the area of innovation dynamics assessment has confirmed that it is possible to construct such an index which would a) measure changes over time for a group of countries as well as for a single country; b) take into account any number of time moments; c) meet the postulates presented in the paper. The obtained results can be a valuable source of information for policy makers, business practitioners and social activists on the assessment of changes occurring over time in implemented instruments supporting innovative activity in the economy and society. Similar analyses, depending on the needs, can be carried out for a selected period of time and any sub-periods. Supporting the conducted analyses with studies carried out on cross-sectional and longitudinal samples, allowing for the use of lagged panel data models, may prove particularly valuable. Due to the extensive application possibilities of the proposed index, the authors plan further work and research on the issues 
considered in the paper. In particular, future research on theoretical grounds will be focused on the analysis of the selection of the optimal system of weights as well as the determination of the probability distribution of the presented index (treated as a random variable), hence the confidence interval for the actual change in the level of innovativeness. It is planned to analyse the impact of using another basis for calculating weights for neighbouring time moments than the harmonic mean. On the basis of empirical analyses, the authors plan to prepare forecasts for further development over time of the dynamics of innovativeness (e.g.: through statistical trend analysis) and to repeat all the analyses presented in the paper but taking into account another (than the SII) innovation index (e.g.: the Global Innovation Index or the Innovation Output Indicator). As in every scientific work, the authors have encountered various limitations in carrying out empirical research. In 2016, there were changes in the SII methodology, however the updating of rankings from previous EIS editions has been carried out only since 2010. Thus, the data for 2008-2009 have become incomparable with the latest data. This has made it impossible to extend the time series by two units of time. At the same time, it is also impossible to include data from 2017 in the analyses made with the proposed index. If such data are available for the SII, they have not been published by the Eurostat for particular weights which the authors consider in this paper. However, the described limitations do not constitute an obstacle to conducting further in-depth analyses. When constructing the index for two compared periods, it was assumed that it had the form of a weighted arithmetic mean of partial indices (formula (3)). It was a subjective choice of the authors, although obviously the possibility of using a different type of weights, e.g.: weighted geometric mean, exists. It was also assumed that the changes (increments) of partial indices were independent of each other (it was assumed that $d I_{i}^{s, t}$ and $d I_{j}^{s, t}$ were independent random variables), which seems to be quite a natural assumption, but it should be verified in practice. We assumed also that corresponding volatility coefficients calculated for the Summary Innovation Index at considered moments $s$ and $t$ approximated each other (see (14)). This assumption also seemed natural to us, especially as the final index formula compares the values for two adjacent periods. In the perspective of a relatively short period of time which divides them (one year), unless there is an extraordinary event that may disturb the innovativeness of economies (war, cataclysm, etc.), there should be no significant differences in the relative volatility of any innovation index. Formally, however, also this assumption should be verified.

Finally, a certain internal limitation of the developed method is the point score generated by the index, which is also a weakness indicated in the general theory of price indices. In practice, the statement that the index value sought is within a certain numerical range with a predetermined probability (confidence level) might be a more valuable piece of information. Such an approach, used in inferential statistics (the so-called confidence intervals), would, however, require knowledge of probability distributions of partial indices of SII dynamics, which necessitates further research in this area. In the future, the authors plan to analyse the probability distributions of the considered innovation indices and how these distributions change over time. In the most general case, therefore, the final indices of dynamics of innovativeness should be treated as a stochastic process, which is also included in the authors' scientific plans. 


\section{Author contributions}

Elżbieta Roszko-Wójtowicz and Jacek Białek were responsible for the design and development of the data analysis. Elżbieta Roszko-Wójtowicz and Jacek Białek contributed to data collection and data analysis and were responsible for data interpretation.

\section{References}

Acs, Z., Audretsch, D. B., Braunerhjelm, P., \& Carlsson, B. (2009). The knowledge spillover theory of entrepreneurship. Small Business Economics, 32(1), 15-30. https://doi.org/10.1007/s11187-008-9157-3

Andersson, Å. E., \& Beckmann, M. J. (2009). Economics of knowledge: theory, models and measurements. Cheltenham: Edward Elgar Publishing.

Andersson, M., \& Ejermo, O. (2004). Sectoral knowledge production in Swedish regions 1993-1999. In Knowledge spillovers and knowledge management (pp. 143-170). Northampton, UK.

Balk, M. (1995). Axiomatic price index theory: a survey. International Statistical Review, 63, 69-95. https://doi.org/10.2307/1403778

Balk, B. M. (2016a). A review of index number theory. In Wiley StatsRef: statistics reference online. John Wiley \& Sons, Ltd. https://doi.org/10.1002/9781118445112.stat07880

Balk, B. M. (2016b). Various approaches to the aggregation of economic productivity indices. Pacific Economic Review, 21(4), 445-463. https://doi.org/10.1111/1468-0106.12192

Białek, J. (2007). Agregatowy indeks przeciętnej wydajności pracy. Wiadomości Statystyczne, 8, 1-13.

Białek, J., \& Czajkowski, A. (2008). A proposition of the system of weights for aggregative indexes on the example of the index of work efficiency. Acta Universitatis Lodziensis, Folia Oeconomica, 216, 333-341.

Bogliacino, F., Piva, M., \& Vivarelli, M. (2012). R\&D and employment: An application of the LSDVC estimator using European data. Economics Letters, 116, 56-59. https://doi.org/10.1016/j.econlet.2012.01.010

Bogliacino, F., \& Vivarelli, M. (2012). The job creation effect of R\&D expenditures. Australian Economic Papers, 51, 96-113. https://doi.org/10.1111/j.1467-8454.2012.00425.x

Chatzkel, J. L. (2004). Human capital: The rules of engagement are changing. Lifelong Learning Journal in Europe, 9(3), 139-145.

Clements, K. W., \& Selvanathan, E. A. (2007). More on stochastic index numbers. Applied Economics, 39(5), 605-611. https://doi.org/10.1080/00036840500439093

Dobni, C. B. (2010). Achieving synergy between strategy and innovation: The key to value creation. International Journal of Business Science and Applied Management, 5(1), 48-58.

Drucker, P. F. (1992). The age of discontinuity: guidelines to changing our society. USA: Transaction Pubs.

European Commission. (2018). European Innovation Scoreboard 2018. Luxembourg: Publications Office of the European Union.

Feldmann, H. (2013). Technological unemployment in industrial countries. Journal of Evolutionary Economics, 23, 1099-1126. https://doi.org/10.1007/s00191-013-0308-6

Firszt, D. (2012). Uwarunkowania dyfuzji innowacji w polskiej gospodarce. Warszawa: CeDeWu.

Fisher, I. (1922). The making of index numbers. Boston: Houghton Mifflin.

Geng, X., \& Huang, K. G. (2016). Informal institutions and the geography of innovation: An integrative perspective. In Global innovation and entrepreneurship: challenges and experiences from East and West (pp. 61-78). Singapore: Research Collection Lee Kong Chian School of Business. Retrieved from http://ink.library.smu.edu.sg/lkcsb_research/5124 
Hall, B. H., Griuches, Z., \& Hausman, I. (1986). Patents and R\&D: is there a lag? International Economic Review, 27, 265-283. https://doi.org/10.2307/2526504

Horth, D. M., \& Vehar, J. (2014). Becoming a leader who fosters innovation. Greensboro, NC: Center for Creative Leadership.

Huarng, K., \& Mas-Tur, A. (2016). New knowledge impacts in designing implementable innovative realities. Journal of Business Research, 69(5), 1529-1533. https://doi.org/10.1080/10496491.2016.1190219

Johansson, B. (2014). Generation and diffusion of innovation. In Handbook of regional science. Berlin: Springer. https://doi.org/10.1007/978-3-642-23430-9_23

Jones, C. I. (2016). The facts of economic growth. In J. B. Taylor \& H. Uhlig (Eds.), Handbook of macroeconomics (Vol. 2, pp. 3-69). https://doi.org/10.1016/bs.hesmac.2016.03.002

Karlsson, Ch., Johansson, B., \& Norman, T. (2011). Innovation, technology and knowledge (CESIS Electronic Working Paper No. 247). The Royal Institute of technology Centre of Excellence for Science and Innovation Studies (CESIS).

Lu, Y., Tsang, W. K., \& Peng, M. W. (2008). Knowledge management and innovation strategy in the Asia Pacific: toward an institution-based view. Asia Pacific Journal of Management, 25, 361-374. https://doi.org/10.1007/s10490-008-9100-9

Machin, S. (2001). The changing nature of labor demand in the new economy and skill-biased technology change. Oxford Bulletin of Economics and Statistics, 63, 753-776. https://doi.org/10.1111/1468-0084.63.spe1.8

Mačiulytė-Šniukienė, A., \& Matuzevičiūtè, K. (2018). Impact of human capital development on productivity growth in EU Member States. Business. Management and Education, 16(1), 1-12. https://doi.org/10.3846/bme.2018.66

Madsen, J. B. (2008). Innovations and manufacturing export performance in the OECD countries. Oxford Economic Papers, 60, 143-167. https://doi.org/10.1093/oep/gpm014

Martini, M. (1992). A general function of axiomatic index numbers. Journal of the Italian Statistics Society, 1(3), 359-376. https://doi.org/10.1007/bf02589086

Niklewicz-Pijaczyńska M., \& Wachowska, M. (2012). Wiedza - kapitał ludzki - innowacje. Wrocław: Prawnicza i Ekonomiczna Biblioteka Cyfrowa.

Olt, B. (1996). Axiom und Struktur in der statistischen Preisindextheorie. Frankfurt: Peter Lang.

Peng, M. W. (2006). Global strategy. Cincinnati: South-Western Thomson.

Piva, M., \& Vivarelli, M. (2009). The role of skills as a major driver of corporate R\&D. International Journal of Manpower, 30, 835-852. https://doi.org/10.1108/01437720911004452

Rao, D. S. P., \& Hajargasht, G. (2015). Stochastic approach to computation of purchasing power parities in the International Comparison Program (ICP). Journal of Econometrics, 191(2), 414-425. https://doi.org/10.1016/j.jeconom.2015.12.012

Raymond, W., Mairesse, J., Mohnen, P., \& Palm, F. (2015). Dynamic models of R\&D, innovation and productivity: panel data evidence for dutch and french manufacturing. European Economic Review, 78, 285-306. https://doi.org/10.1016/j.euroecorev.2015.06.002

Roberts, M., \& Vuong, V. A. (2013). Empirical modeling of R\&D demand in a dynamic framework. Applied Economic Perspectives and Policy, 35(2), 185-205. https://doi.org/10.1093/aepp/ppt011

Roszko-Wójtowicz, E., \& Białek, J. (2017). Evaluation of the EU countries innovative potential - multivariate approach. Statistics in Transition New Series, 18(1), 167-180. https://doi.org/10.21307/stattrans-2016-064

Roszko-Wójtowicz, E., \& Białek, J. (2018). The size of the substitution bias of inflation measurement in relation to the level of innovativeness of the European Union's economies. Econometrics. Advances in Applied Data Analysis, 22(4), 79-97. 
Santos, J., Doz, Y., \& Williamson, P. (2004). Is your innovation process global? Sloan Management Review, 45(4), 31-37.

Savrul, M., \& Incekara, A. (2015). The effect of R\&D intensity on innovation performance: a country level evaluation. Procedia - Social and Behavioral Sciences, 210, 388-396. https://doi.org/10.1016/j.sbspro.2015.11.386

Selvanathan, E. A., \& Rao, D. S. P. (1994). Index numbers: a stochastic approach. Ann Arbor: The University of Michigan Press. https://doi.org/10.3998/mpub.13784

Selvanathan, E. A. (1989). A note on the stochastic approach to index numbers. Journal of Business and Economic Statistics, 7(4), 471-474. https://doi.org/10.1080/07350015.1989.10509759

Shanhong, T. (2002). Knowledge management in libraries in the twenty-first century. Journal of Science Relationship, 3, 72-77. https://doi.org/10.1515/9783110956238.88

Steinmueller, W. E. (2010). Economics of technology policy. In Handbook of the economics of innovation (pp. 1192-1214). Amsterdam: Elsevier. https://doi.org/10.1016/S0169-7218(10)02012-5

ter Haar, P. (2018). Measuring innovation: A state of the science review of existing approaches. Intangible Capital, 14(3), 409-428. https://doi.org/10.3926/ic.1254

Toffler, A., \& Toffler, H. (1980). The third wave. New York: William Morrow. Retrieved from http:// www.swo.ae.katowice.pl/_pdf/226.pdf

Vancauteren, M., Melenberg, B., Plasmans, J., \& Bongard, R. (2017). Innovation and productivity of dutch firms: a panel data analysis. Retrieved from https://www.cbs.nl/nl-nl/achtergrond/2017/44/ innovation-and-productivity-of-dutch-firms

Veugelers, R. (2010). Towards a multipolar science world: trends and impact. Scientometrics, 82, 439456. https://doi.org/10.1007/s11192-009-0045-7

Vila, L. E., Cabrer, B., \& Pavía, J. M. (2015). On the relationship between knowledge creation and economic performance. Technological and Economic Development of Economy, 21(4), 539-556. http://doi.org/10.3846/20294913.2013.876687

von der Lippe, P. (2001). Chain indices: a study in index theory. Wiesbaden: Federal Statistical Office Germany.

von der Lippe, P. (2007). Index theory and price statistics. Frankfurt: Peter Lang. https://doi.org/10.3726/978-3-653-01120-3

Węgrzyn, G. (2015). Wykształcenie i kwalifikacje pracowników jako determinant zmian w poziomie innowacyjności gospodarek. Ekonomia XXI wieku, 1(5), 10-18.

Wiig, H., \& Wood, M. (1995). What comprises a regional innovation system? - an empirical study (STEP Working Paper No. 01). Retrieved from https://www.researchgate.net/publication/275614827_Innowacyjnosc_Input-Output_regionow_grupy_wyszehradzkiej

Williams, R., Slack, R., \& Stewart, J. (2000). Social learning in multimedia: final report. EC targeted socio-economic research project: 4141 PL 951003. Edinburgh, Scotland: Research Centre for Social Sciences, The University of Edinburgh.

Witkowski, B., \& Weresa, M. A. (2006). Wpływ innowacji na konkurencyjność branż polskiego przemysłu. In Polska. Raport o konkurencyjności 2006. Rola innowacji w kształtowaniu przewag konkurencyjnych (pp. 202-214). Szkoła Głowna Handlowa w Warszawie, Warszawa. 